\title{
History as engagement: The Historical Epistemology of Raymond Aron
}

MASSIMILIANO SIMONS, Ghent University

Abstract: Raymond Aron was a student of Léon Brunschvicg, a representative of French historical epistemology. This article explores Aron's relation to this tradition through three claims. First of all, it contests that Raymond Aron's philosophy of history constituted a complete break with this tradition. Secondly, resituating Aron in this tradition is valuable, because it highlights how Aron's own philosophy of history is to be understood as a normative project, seen as an alternative to that of Brunschvicg. Finally, Aron's philosophy can still hold valuable lessons for present-day historical epistemology and history and philosophy of science in general.

Acknowledgments: The research for this article was funded by the Research Foundations Flanders (FWO). An earlier version of this paper was presented at the Gèmes Journées d'études sur I'Épistémologie Historique, held online during November 2020. I moreover want to thank Hannes Van Engeland and the two anonymous reviewers for their helpful comments. 


\section{Introduction}

In 1970 the French philosopher Michel Serres wrote a critical essay on Gaston Bachelard's La formation de l'esprit scientifique (1938). In that book Bachelard discussed the distinction between science and pre-science, mapping the numerous 'epistemological obstacles' in the history of science. Serres's text mainly argued for two points. First of all, that Bachelard offered us, not a description of the history of science, but rather a normative evaluation. It is a theory, not of how science is, but of how science should be - or better: how the scientific self should behave (see Chimisso 2001; Simons 2022). According to Serres, in Bachelard's text there is a moral model at work, starting from the ideal of purification: only a self purified from all desires is capable to have access to the truth. "The battle takes place behind history and behind science: what is at stake, is to decide who will finally be the master of knowledge or the owner of history." (Serres 1970, p. 39) Secondly, the issue for Serres is not so much that there is a moral model at work in Bachelard, but that it is the wrong moral model. For Serres, Bachelard's model is incapable to deal with the central problem we're facing in science, summarized in one word: Hiroshima. Science has shown to imply violence, destruction, on a collective level never seen before. "The purity of the soul is child's play in face of this risk." (Serres 1970, p. 45) Hence, Michel Serres could not identify any longer with the project of 'historical epistemology', embodied by Bachelard.

However, let us return to 1938, the year Bachelard's published his book. I want to argue that another philosopher was doing the exact same thing as Serres. But this time the target was not Bachelard, who was only just starting his philosophical career, but rather his teacher: Léon Brunschvicg. The young philosopher, making the same contestation as Serres, was another of his students: Raymond Aron. Again Aron's discontent with his teacher was twofold: (1) Brunschvicg's philosophy of science was more than a description of science, it entailed a moral model of what science should be; (2) and the presence of such a moral model was not the issue, but what was problematic was that is was ill-suited for the times Aron lived in. These were the 1930s, threatened by the rise of Nazism and Totalitarianism. Hence, 30 years before Serres, Aron seemed to abandon the project of 'historical epistemology' for very similar reasons.

This article aims to do three things. First of all, and similar to how it is done concerning the relation between Bachelard and Serres (see Simons 2022), I want to contest that Raymond Aron's philosophy of history should be understood as a complete break with the tradition of French historical epistemology, to which both Brunschvicg and Bachelard belonged (see Chimisso 2008; Braunstein, Diez and Vagellli 2019). Aron's work is typically not discussed as part of the literature on historical epistemology, and this article is a first attempt to do so. Secondly, it wants to argue that this is 
nonetheless valuable, not just from a historiographical point of view, but also because it highlights how Aron's own philosophy of history is to be understood as a normative project on its own, seen as an alternative to that of Brunschvicg. More specifically, as we will see, it is to be understood as a political intervention, which aimed to update philosophy of history in the light of contemporary challenges, such as totalitarianism. Finally, given this recontextualisation of Aron in this tradition, the article ends in its conclusion with a brief exploration of how Aron's philosophy can still hold valuable lessons for present-day historical epistemology and history and philosophy of science in general.

\section{Raymond Aron as historical epistemologist}

Raymond Aron (1905-1983) was a French philosopher, mainly known for his contributions to sociology, liberal political philosophy, and his journalistic interventions in France. If the work of Raymond Aron is discussed, the focus tends to be on his relation to his petit camarade Jean-Paul Sartre (e.g. Barilier 1987; Sirinelli 1995). Both knew each other from a young age, studying together at the École Normale Superieure. The existing literature therefore first of all focuses on how they influenced one another. For instance, it was Aron who, around 1932-1933, came back from Germany and introduced Sartre to a new philosophy: phenomenology. Under the advice of Aron, Sartre would indeed go to Berlin to study phenomenology there. Secondly, the literature focuses on the ultimate break between Aron and Sartre, after the Second World War, where the Marxist Sartre became opposed to the liberalconservative Aron. The emphasis is then on how Aron studied Marx when he was young, only to discover later that Marx' model of history and views on economics were untenable. "The course of the twentieth century refuted the historical view, characteristic of Marx's Marxism." (Aron 1961, p. 40) ${ }^{1}$ As part of this narrative the focus is often on Aron's L'Opium des intellectuels (1955), in which he criticizes his contemporaries - from Sartre to Merleau-Ponty - for falling for the ideology of communism. More recently, authors have started to stress how Sartre's postwar work can be linked to Aron's early philosophy of history as well, especially to Aron's dissertation Introduction à la philosophie de l'histoire (1938a) (see Stewart 2011). Pierre Verstraeten even goes so far to argue that Sartre's Critique de la raison dialectique must be understood as a direct response to the historical relativism of Aron's dissertation (Verstraeten 2008, p. 9). However, the difficulty is, as Stewart has noted, that Sartre "at no point refers explicitly to Aron after the initial critique sketched out in his war diaries." (Stewart 2011, p. 55)

\subsection{The relation between Aron and Brunschvicg}

In this article, however, I wish to situate Aron in relation to another philosopher, namely his supervisor Léon Brunschvicg (1869 - 1944). Brunschvicg was one of the most influential philosopher in Paris at the

\footnotetext{
${ }^{1}$ Translations of French texts are done by the author.
} 
beginning of the twentieth century. Historians have noted how "Brunschvicg's influence on French academic philosophy in the first four decades of the twentieth century was second to none." (Schrift $2006,14)$ With Xavier Léon and Élie Halévy he founded the Revue de métaphysique et de morale in 1893; he played a crucial role in the foundation of the Société française de philosophie in 1901; and, starting from 1909, he taught for 30 years at the Sorbonne. He was the supervisor of a number of very influential French philosophers, ranging from Gaston Bachelard, Jean Cavaillès to Albert Lautman, and also taught Simone de Beauvoir, Georges Canguilhem, Emmanuel Levinas, Claude Lévi-Strauss, Maurice Merleau-Ponty, Paul Ricoeur and Jean-Paul Sartre.

Brunschvicg's philosophy could be described as a Neo-Kantian or critical idealism (see Terzi 2022). But differently than earlier French Neo-Kantians, such as Jules Lachelier or Jules Lagneau, Brunschvicg focused on the history of science, especially the history of physics and mathematics. Supported by the fact that Bachelard and Cavaillès were among his students, his work is therefore often associated with the tradition of French historical epistemology (Castelli Gattinara 1998; Chimisso 2008).

Among Brunschvicg's students, we also find Raymond Aron. Indeed, Aron later referred to Brunschvicg as "his teacher" (Aron 1945, p. 128). At numerous places Aron would stress the role of two teachers in his education: Alain (pseudonym of Émile-Auguste Chartier) and Brunschvicg (Aron 1981, p. 25). About Brunschvicg, Aron would say:

Among the philosophers there was Brunschvicg. He was, historically, a Neo-Kantian among many others. He impressed us, to some extent, because he had studied the development of mathematical thought, the development of physics. He showed a kind of asceticism in his thought. For him, philosophical thought had to be a reflection on science and had to be done in a rigorous way, precisely by taking scientific thought as a model. He constantly cultivated the great philosophers, and he helped us enter the temple of the great philosophers, a temple from which he excluded himself, he said. (Aron 1981, p. 36)

Although it is known that Brunschvicg was the supervisor of Aron's dissertation in 1938, I want to argue that their relation was more than merely institutional, but had a profound influence on Aron's philosophy and even offers a framework through which we can understand what was central to Aron's own philosophy. To argue for such a profound connection between teacher and pupil, let me start by giving six moments that exemplified the strong relation between both authors.

First of all, Brunschvicg was also the supervisor of Aron's thesis for the diplôme d'études supérieures, which dealt with Kant and the intemporal. Although long lost due to the war, it resurfaced in the 1980s due to the discovery of the widow of Albert Lautman, who found a copy among Lautman's old papers (Colquhoun 1986, p. 30). More broadly, Aron later will speak of a whole 'Kant year', under the influence 
of Brunschvicg: "I devoted a whole year to Kant, for the diplôme d'études. There was Brunschvicg who, at the same time, transferred the sense of the great philosophers and discouraged you from prolonging them." (Aron 1981, p. 27)

Secondly, there was an extensive review by Aron of one of Brunschvicg's publications, La connaissance de soi (1931). In this extensive review, Aron would not only describe Brunschvicg's position, but already started to develop his own (Aron 1932). The review highlights a strong familiarity with the whole oeuvre of Brunschvicg, to which Aron still seems to be sympathetic at that time.

Thirdly, and in a similar vein, Aron wrote a long manuscript (apparently over 100 pages) on Brunschvicg's thought while Aron was in Germany in the early 1930s. Though lost, the manuscript was not only an exposition of the philosophy of his teacher, but also, under the influence of Karl Mannheim's sociology of knowledge, an attempt to explain the Brunschvicg's work by its historical and sociological context. Again Aron would later report:

When I wrote a long study on Léon Brunschvicg, to get rid of his influence, there were even passages where I interpreted certain aspects of his thinking by the fact that he was bourgeois, Jewish, and all that! He didn't like it at all, not at all. It was not said in an aggressive manner, but the French philosophers of the Sorbonne did not imagine that they could be 'sociologized'. (Aron 1981, p. 39)

Though Brunschvicg appreciated the first part, which gave an exposition of his philosophy, he was indeed unimpressed by the second, sociological part. Eventually Brunschvicg left the decision whether or not to publish the manuscript to Aron himself. The latter decided against it.

Fourthly, there is the doctoral dissertation. As others have explored already, Aron initially had a different topic, namely individuality in genetics and Mendelism (see Gabe 2018). In fact, in 1930 Aron's original plan was to write a secondary thesis on Le Mendélisme: essai d'épistémologie et de critique (Mendelism : An Epistemological and Critical Essay) and a principal thesis called an Essai d'une philosophie du socialism (Essay on a Philosophy of Socialism) (Colquhoun 1986, p. 50). Aron, indeed still self-identified as a socialist before the war, and similarly the 1932 review mainly consists of an attempt to confront Brunschvicg's notion of the progress and development of science with the biological notion of evolution (see Aron 1932). The choice for biology was, one again, inspired by Brunschvicg, though Aron would abandon it after a year:

I had spent a year studying various books of biology, in particular the genetics of Mendel and Morgan, at a time when the chair in general biology at the Sorbonne was occupied by Etienne Rabaud, who rejected in one stroke the whole of genetics. The thesis subject suggested to me by Léon Brunschvicg was based, if I remember correctly, on the notion of the individual or of 
individuality in the realm of living matter. At the end of a year, I had enough sense to realize that I had better either become a biologist or else leave to the biologists the task of criticizing their science. At best, I would only have been able to approach the level at which the best biologists, conscious of their profession, establish themselves with ease. (Aron 1978, p. xviii) Instead Aron shifted to the philosophy of history. This fourth event is crucial, at least for two reasons. One is that, as Gabel (2018) argues, Aron's turn to philosophy of history was in part inspired by issues he was confronted with in biology. Dismissing both Darwinism and Mendelism, French debates linked to biologists such as Étienne Rabaud and Maurice Caullery mainly concerned questions to what extent neo-transformist models, inspired by Lamarck, could explain the morphology of living organisms and their histories.

On the one hand paleontologists had presented a significant set of historical facts about how different species had existed at different times. On the other hand, evolutionary biologists tried to experimentally assess how organisms could indeed change and be changed. But how these two bodies of facts related to one another was unclear. In other words, in biology the question of how the present relates to the past became central. In order to save his theory, Caullery even went so far as to argue that different mechanisms had operated in the past than those that could be observed today, thereby making the history of evolution unintelligible and inaccessible.

Despite not being focused on biology anymore, these debates still shaped the first chapters of Aron's new dissertation, since it highlighted for him how biologists and historians faced parallel explanatory limits:

In this way, the fundamental distinctions arise between establishing historical facts and explaining changes. The paleontologist, based on documents (fossils), reconstructs the successive forms, but the fact of succession does not logically impose the hypothesis of descent, and this hypothesis itself does not solve the problem of the mechanism of evolution. (Aron 1938a, p. 29)

His initial focus on biology thus brought him to the problem of historical interpretation. But it is also brought him to another issue, that will be once again central to his dissertation and later work. This concerned a circularity of humans being both the subject and the object of evolution: the ones who try to study history are also the product of this history. For Aron, as we will see, this results in a central reflexive role of history: historical narratives are not there only as neutral description of humanity, but are also a part of the history of humanity, i.e. tools that humans have used to understand and shape their own history. "Man was an animal whose essence was not animal, but historic. Like other animals, 
Aron suggested, humans were indeed biological, subject to evolution and natural law. Unlike other animals, man looked at himself, and when he did so, saw history." (Gabel 2018, p. 14)

Besides the direct inspiration by biological themes on his future work, there is also a second reason why this event is crucial to define Aron's position in relation to that of Brunschvicg's. By passing from biology to history, Aron also evaded the typical structure Brunschvicg imposed on all his students, namely the absolute centrality of becoming acquainted in the most thorough way possible with an natural science and its historical development. This was, for instance, the case for Gaston Bachelard, Jean Cavaillès and Albert Lautman, who each focused on a detailed study of a certain episode in physics or mathematics. As a result, in their projects, philosophy often risked to become secondary in relation to their objects of study, for which the philosophies were often mere tools to make them intelligible. Aron's shift towards the philosophy of history, however, created a greater freedom on how to approach the subject and his dissertation.

At that time, Aron was teaching in Germany, where he got acquainted with new developments in German philosophy. His second, revised plan was therefore to write a dissertation on the critical philosophy of history of Wilhelm Dilthey, Georg Simmel and Max Weber. His complementary thesis would be on the philosophy of historical relativism in authors such as Ernst Troeltsch, Max Scheler, Karl Mannheim and Oswald Spengler. However, when Aron sent a first draft of his thesis to Brunschvicg, the later was skeptical whether a reflection on unknown German philosophers was a suitable subject for a dissertation. Aron, once again, followed Brunschvicg's advise and downgraded the project to his complementary thesis, while his main thesis would be an attempt to develop his own philosophy of history.

This became Aron's Introduction à la philosophie de l'histoire (1938a), stressing the limits to objective knowledge about history and the existence of a plurality of historical perspectives. The defense of the dissertation famously caused a stir. The jury members, Brunschvicg, Emile Bréhier and Maurice Halbwachs, were each critical in their own way. The audience, and later reviews, would describe the stir as a 'clash of generations', a claim to which we will return. Brunschvicg's own reaction similarly seemed negative: "Having expressed his admiration for Aron's talent, he did not hide his disappointment, both at the way in which Aron chopped up his problems and at the apparent gap between Aron's thought and his own." (Colquhoun 1986, p. 144)

Fifthly, Aron would cause another stir one year after the defense, when on 17 June 1939 Aron gave a lecture at the Société française de philosophie on the difference between democratic and totalitarian states (see Aron 1946). He argued that the main struggle of the $20^{\text {th }}$ century was not so much the struggle between fascism and communism, but between totalitarian ideologies and liberal democracy. 
The latter was in need of a stronger defense against the rising threat of totalitarianism. To be a liberal, meant to be conservative about the liberal and even Christian values embodied by democracy. This called for a form a political action which would dare to abandon pacifism and develop the necessary virtues of combat, similar to those of totalitarianism. Again the discussion afterwards was heated, many contesting Aron's interpretation of democracy and his call for political action. The lecture itself is not only symbolically important because of how it anticipated the outbreak of the Second World War, which would start only a few months after, but also that it was the last meeting of the Society to be held under Brunschvicg's Presidency.

Whereas Aron would end up in the United Kingdom during the war, Brunschvicg would escape to the south of France, having to flee multiple times to eventually die in January 1944 . This brings us to the final and sixth element that I wish to highlight, namely the special issue of the Revue de morale et métaphysique which was published one year later on Brunschvicg's philosophy. It did not only include contributions from scholars such as Bachelard, Louis de Broglie, Maurice Blondel, but also a text by Aron, where once again Aron would define his own thought in relation to "his teacher" (Aron 1945, p. 128). We will come back to this text.

\subsection{The model of the break}

If there is such an extensive relation between Aron and Brunschvicg, how must we understand it? To the extent that there is reflection on this topic at all, the dominant model is that of a break: Aron broke with his teacher, Brunschvicg. In the reflections of Aron and contemporaries, such as Sartre or Paul Nizan, one find the theme that they installed a break with the generations of their teachers, ranging from Brunschvicg, Alain, Célestin Bouglé to André Lalande. The most exemplary case is Nizan, a close friend of Aron and Sartre at that time, who in his book Les Chiens de Garde (1932) attacked his teachers. According to Nizan, especially the function of Brunschvicg's philosophy was only

to obscure the miseries of contemporary reality: the spiritual destitution of vast numbers of men, the fundamental dichotomy in their consciousness, and the increasingly intolerable disparity between what they could achieve and what little they have actually accomplished [...]. It serves to divert the exploited from the contemplation of their own degradation and debasement - an activity that might prove dangerous to the exploiters [...]. In a word, the purpose of this philosophy is to explain, to fortify, and to propagate the half-truths manufactured by the bourgeoisie and so useful in consolidating its power. (Nizan 1932, pp. 91-92)

Commentators have therefore characterized the 1920s and 1930s as an anti-positivist turn in France, revolting against both the idealism of the dominant philosophers and also against Durkheimian 
sociological positivism (e.g. Stewart 2011, p. 42). There was an overemphasis on epistemology and the sciences in the curriculum, lacking any proper political philosophy (Colquhoun 1986, p. 29).

According to this story, German philosophy was typically seen as the alternative, which was hardly taught in France at that time. Instead, it either came from (academic) outsiders such as Bernard Groethuysen, Alexandre Kojève, Eric Weil and Alexandre Koyré, or by literally going to Germany and learn it there. ${ }^{2}$ This was the case for Aron, who went to Germany from March 1930 to August 1933, where he experienced the rise of Nazism firsthand. Later, Aron would recount how this experience

forced me to think against myself, against my intimate preferences, it inspired in me a kind of revolt against the teaching received at the university, against the spiritualism of philosophers, against the inclination of certain sociologists to ignore the impact of regimes, under the pretext of attaching themselves to lasting and deep realities. (Aron 1971, p. 12)

Similarly, in a later interview Aron would state how "the four years of the École Normale prepared me to become a philosophy teacher in a high school, but nothing else." And he continues:

I was almost desperate that I wasted years learning next to nothing. I was exaggerating because the formation to read great philosophers is not sterile. But all the same I knew very little about the world, about social reality, about modern science. So what? Philosophy on what? On nothing? Or do one more thesis on Kant? So I fled, in a way. (Aron 1981, p. 27)

While in Germany, so the narrative goes, Aron discovered a superior alternative philosophical model: (a loosely) Kantian critical philosophy of history, linked with authors such as Wilhelm Dilthey, but especially Max Weber (Aron 1981, p. 38). For Aron, these philosophers stressed correctly how there are limits of objective knowledge in history: we can never uncover fixed historical laws that would explain its process. Instead, for someone like Dilthey:

The historian grasps, or at least thinks he is grasping, the whole of an epoch, a work or a development. Yet the intelligibility of historical successions, the imminence of the whole within the elements hardly implies the adequacy of scientific concepts in relation to the real. On the contrary, the fact that the human past is immediately intelligible has as its inevitable consequence the plurality of retrospective interpretations. (Aron 1938b, p. 105)

As a consequence, we find in Aron a stress on the role of understanding (Verstehen): the historian must always interpret history from his or her particular point of view, without pretending that it is an

\footnotetext{
${ }^{2}$ It should be noted moreover that Kojève, Weil and Koyré were all linked to the École pratique des hautes études (EPHE), an institution which was partly designed to offer alternative courses to those provided by the Sorbonne. Part of the inspiration to create the EPHE was also a plea, among others by Ernest Renan, to renew French education in the light of its German counterpart. I thank one of the reviewers for stressing this point.
} 
absolute point of view. Aron would also take over the distinction, typically explored in German philosophy, between human and natural sciences, and the specificity of historical knowledge: "Physics aims for the law, history the singular." (Aron 1961, p. 15)

It was this German philosophy of history that Aron would put at the center of his doctoral dissertation and would later also mobilize to criticize the pretentions of Marxist historiography (Aron 1955). In his dissertation his conclusions were radical, often flirting with relativism, and it was no surprise that they provoked wonder and confusion among his teachers. Aron would, for instance, conclude:

One fundamental idea emerges, it seems, from the preceding discussions: the dissolution of the object. No such thing as historical reality exists ready-made, so that science merely has to reproduce it faithfully. Historical reality, because it is human, is ambiguous and inexhaustible. The meanings of man for man, of the masterpiece for its interpreters and the past for succeeding generations are inexhaustible. (Aron 1938a, p. 147)

The result was a number of strong criticisms from his jury, with the sociologist Paul Fauconnet famously stating that Aron's thesis is "either desperate or satanic" (quoted in Colquhoun 1986, p. 142). Also reviewers of Aron's published dissertation, and witnesses of the defense framed it as a clash between two generations (Groethuysen 1939; Davenson 1939; see Fessard 1980).

Though this generational conflict model seems plausible, there are however a number of problems with it. First of all, the narrative's stress on German Neo-Kantian philosophy as the alternative to French positivism clashes with the fact that Brunschvicg himself was a Neo-Kantian philosopher and one could even say an anti-positivist. Aron would in fact stress how it was through Brunschvicg's influence that he was able to see the value and significance of German philosophy of history: “Influenced by Léon Brunschvicg's Neo-Kantianism, I found myself in a familiar universe, reading those related to the South West German school." (Aron 1971, p. 13)

Secondly, there was never a real break between Aron and Brunschvicg, certainly not in the same sense as between Aron and Sartre. Although Brunschvicg disagreed with an number of themes in Aron's work, he was at the same time very positive about Aron's first book on German sociology, already published in 1935 (Aron 1935; Colquhoun 1986, p. 110). Aron also later recalled how his dissertation "surprised the members of the jury, but the three leading judges at the university - Henri Bergson, Léon Brunschvicg, and Lucien Lévy-Bruhl - expressed, both publicly and privately, flattering or indulgent opinions. As a thesis, but also in the intellectual world at large, the book was a success." (Aron 1978, xxi) On his turn, Aron would later state how he still has "the greatest respect" for Brunschvicg (Aron 1975, ix) and would even defend him against the attacks by, among others, Nizan. Aron found Nizan's book terrible: "Our teachers did not deserve such insults for the sole crime of not 
being revolutionaries. Why should they have been?" (quoted in Colquhoun 1986, p. 28) Aron also tells the story of how "this same Nizan, who had written his appalling book against the professors of the Sorbonne, in 1937 or 38 wrote a letter or a work with a kind or respectful dedication to Brunschvicg. Brunschvicg had told me about it." (Aron 1981, p. 47)

Thirdly, Aron's problem with his professors was not so much its model of history, but rather what he called "their irreducible optimism, their indifference to Marx, their tendency to neglect the struggles, sometimes inexpiable, between classes, parties and ideas." (Aron 1971, p. 12) As we will see, the disagreement situated itself rather on the political level, instead of on the level of theory or description.

Finally, Aron's 'flight' to Germany was not so much a break with the French tradition, but part of an existing tradition of French scholars going to Germany. As Aron would later state, "it was something of a tradition that young French sociologists who had been to Germany should, on their return, write about what they had encountered there." (quoted in Colquhoun 1986, p. 99) Durkheim and Bouglé went before him, similarly to learn German philosophy. Especially the work of Célestin Bouglé was important in the case of Aron, who introduced the latter to the work of Karl Marx and German sociology in general. Moreover, Bouglé formed a bridge between the sociologists (working together with Durkheim and the journal L'Année sociologique) and the philosophers (which centered around journals such as Revue de métaphysique et de morale, which was co-created by Brunschvicg). In addition, Aron also stresses that part of his motivation to go to Germany was not to oppose France and Germany, but to bring them together, in line of the pacifist program of his teacher Alain. "You know, we in our generation hated, really, hated and despised the intellectuals who condemned German culture because of the 1914-18 war against Germany." (Aron 1981, p. 29) His message was one of peace, of Franco-German reconciliation.

\subsection{A clash between ethics and politics}

If the model of a break is inadequate, is there an alternative to understand the relation between Aron and Brunschvicg? In this section, I want to propose a reading that suggests that the disagreement between Aron and Brunschvicg was related to a different element, namely Brunschvicg's moral model of science. Or as Aron states:

Like all philosophers worthy of the name, Léon Brunschvicg was above all a moralist. Most of his books are apparently devoted to the history or criticism of science, but the ultimate subject they deal with, the real question that guides them, is the question that man has never ceased to ask himself over the centuries: 'What is man?' Or again: Know thyself'. (Aron 1945, p. 129) 
Following Aron, we could summarize Brunschvicg's philosophy by two principles. ${ }^{3}$ First of all, there is was we could call the relativization of the self. The mature and rational subject, according to Brunschvicg, is the one who is able to realize that there are other points of views, who is capable to transcend its own point of view. The scientific mind "learns to see himself from another's point of view just as he sees others from his own point of view." (Brunschvicg 1927, p. 721) Brunschvicg also refers here to the work of the developmental psychologist Jean Piaget, who similarly argued that a child grows up if it is capable to realize that there are other perspectives besides that of him- or herself (Piaget 1926). Or as Aron summarizes:

The world as it presents itself to the child is made of real, hard objects, the very ones our perception presents to us, and so the child relates this dreadful world to himself. In other words, in philosophical terms, realism and egocentrism go hand in hand, as do the two discoveries that the world is our representation and that humanity is not the center of the world. This is why in the eyes of Léon Brunschvicg, the discoveries of Copernicus mark an equally decisive date in the history of the human mind as the doctrines of Descartes and Kant. Copernicus puts the earth and humanity in their place, in a universe that is not made for them. (Aron 1945, pp. 131-132)

The same lesson is drawn from Einstein's theory of relativity: "Instead of accepting space and time as fixed frames, ready-made realities outside of us, science itself, in its spontaneous development, reinstated the consideration of the subject to explain phenomena." (Aron 1945, p. 132) This leads to the second principle of Brunschvicg's philosophy, which we could call his emancipatory idealism. Not only are there multiple points of view, but these viewpoints are shaped and created by the subject. We are thus not a slave of some fixed natural or transcendental framework, but have the capacity and even the duty to revise our point of view. In that sense, progress is central for Brunschvicg's philosophy. Brunschvicg, however, does not restrict this framework to science, but applies it to the ethical and political sphere as well. The scientist is, in a sense, the moral model of the subject in all societal spheres. In that sense, Brunschvicg links Einstein with Socrates, often using the example of Socrates teaching his son Lamprocles to take the position of his mother, Xanthippe. Lamprocles "had to understand that he was not an individual 'closed on itself', but that he was a son placed in a relation to a mother who has risked her life in bringing him into this world and who has fed and cared for him." (Brunschvicg 1923, p. 360) In both cases, in science and in ethics, understanding brings a plurality of perspectives and offers the subject the capacity to create new points of views. "This complex and subtle function,

\footnotetext{
${ }^{3}$ The secondary literature on Brunschvicg is limited, especially in English. For a good overview, though, see Terzi (2022).
} 
which Einsteinian science thus places at the heart of human intelligence, is exactly what we saw at work in the Dialogues of Socrates." (Brunschvicg 1927, p. 721) Or again to cite Aron's summary:

To overcome himself, to escape his moods and desires, the honest, moral person must make the same effort that the scientist makes to think the true relationship. Socrates advising the mother to place herself at the point of view of the son to understand her duty towards him, advising the son to place himself at the point of view of the mother to understand his duty towards her, gives us the first example of this disinterestedness, of this reciprocity of perspectives of which Einstein's physics is, in the theoretical order, the completed model. (Aron 1945, p. 133)

As I said in the introduction, Aron's issue with Brunschvicg has to do with his implicit moral model. But this does not mean that Aron finds Brunschvicg's moral stance wrong or even unethical. That Aron does appreciate Brunschvicg's take is shown in these early texts, but also in his strong appreciation of Brunschvicg's other student, Jean Cavaillès. Aron and Cavaillès knew each other well. Cavaillès defended his dissertation just two months before Aron and would himself report how he was impressed by Aron's dissertation. They would moreover start a book series with Hermann (see Cavaillès and Aron 1939). Also during the war, when Cavaillès was sent on a mission to London, he would stay with Aron (see Colquhoun 1986, p. 236).

In the preface to Cavaillès's Philosophie mathématique, Aron would praise his ethical stance. According to Aron, Cavaillès "insisted on the necessity, which dictated the practical imperatives as well as the scientific proposals, 'I am a Spinozist', he said, 'we must resist, fight, face death. So truth, reason demands." (Aron 1962, p. 14) Cavaillès actions indeed showed "the limits of politics seen as a combination of effective means for desirable ends. He too once said: 'This is my position, I cannot help it'." (Aron 1962, p. 16) Aron greatly appreciated and admired the ethical stance of his friend, and in that sense he did not outright dismiss such moral models, but he was skeptical whether it could be generalized to the appropriate political strategy.

The same kind of ambiguity seems to characterize Aron's take on Brunschvicg's moralism. The problem is not so much that there is a moral model, but that this model is not the appropriate model for the problems we are faced with in the 1930s and 1940s. To make this point, Aron would contrast Brunschvicg with another tradition, which he encountered in Germany namely phenomenology (ranging from Husserl and Heidegger to the social phenomenology of Alfred Schütz). The phenomenological approach highlights the actual, daily lives and practices, whereas Brunschvicg's moral model portrays a highly idealized and abstract picture of the moral subject. Such an idealized 
model, however, was unable to deal with the reality and irrationality of Nazism. As Aron would summarize in a later text:

Léon Brunschvicg wanted the moralist to take as an example and a model the attitude of the scientist, detached from himself, subject to experiment and to reason, erasing his ego in order to open up to the truth. Alas, which scientist behaves as a scientist as soon as he leaves his laboratory or takes part in political debates? (Aron 1971, p. 24)

In that sense, as Aron already concluded in 1945, Brunschvicg's "deeply historical philosophy is in a way out of date. [...] Brunschvicg is our contemporary, but he is Einstein's contemporary, not Hitler's." (Aron 1945, p. 138)

\section{Political philosophy of history}

My proposal therefore is to interpret Aron's philosophy of history not so much as a theoretical correction of the positivism of his days, but rather as a political intervention. It followed mainly from an attempt to articulate an adequate political response to the rising threat of fascism and totalitarianism. This is also how Aron opened his doctoral defense, at a time when he still self-identified as a socialist:

Why am I a socialist? What does it mean to have a political position? These were the questions that I asked myself while studying Marxism and political economy. Very quickly, it occurred to me that in this matter desire and knowledge mutually determine and limit each other. But noting that value judgements and judgements of reality are thus linked raised a larger problem anterior to the determination of the political will, that of sociological and historical knowledge [connaissance]. The critique of historical thought and the logical of political thought condition one another. (cited in Fessard 1980, p. 42)

He would endorse this interpretation also in his later memoirs: "The whole book clarified the mode of political thought that would henceforth be my own - and which remains so in the autumn of my life" (Aron 1983, p. 125). To the extent that it is a critique of the tradition of historical epistemology, it is one of its political project.

In this second part, therefore, I wish to flesh out Aron's philosophy of history as a political project, which starts from two paradoxical principles. First of all, inspired by Weber, the idea that history is plural: there is not one correct interpretation of history, but instead a plurality of points of views (3.1.). Secondly, inspired by phenomenology, Aron defends the claim that humans are at the same time historical beings in need of such a unifying historical point of view (3.2.). Thus, while human existence implies the desire and need for such an all-encompassing point of view, this is impossible from a 
scientific or objective point of view. I will subsequently focus on how Aron nevertheless aims for a framework that combines both principles.

\subsection{History as plurality}

The first principle of Aron's philosophy of history is inspired by Max Weber. I will be just briefly summarize Aron's interpretation of Weber, since it has been scrutinized by others (see Breiner 2011). Following German philosophy of history in general, and Weber in particular, Aron contrasts the natural and the human sciences. The study of history is different from the study of natural objects, since it is always a creation by humans. Historical knowledge, moreover, is always about the past. It thus has a specific form in which it exists, namely narratives. Narratives, though constraint by the available facts, are always subjective creations that stress some elements at the cost of others. There exists a "plurality of possible interpretations of humans and their works. This is what is called historical relativism in the interpretation of the past." (Aron 1981, p. 55) There is simply too much messiness and detail in history and any meaningful narrative about it has to make choices. Or in the words of Aron:

I did not want to suggest that each historian tells the story in his own way but that no historian can boast that he has presented the definitive version of the drama; not only is the last word not yet spoken but the intelligible reconstruction of experienced chaos never exhausts the facts or connections capable of appearing in knowledge. (Aron 1978, p. xxiii)

However, for Aron the recognition of this plurality does not result in a form of fatalism. Rather, it should be understood as the phenomenological condition from which one starts. Aron's philosophy of history is sometimes described as the existentialist philosophy of history (Aron 1981, p. 56). Though Aron never accepted the label, it can nonetheless be fruitful to read it in that way. The above plurality is then the situation in which we all find ourselves: we live in a world for which there is no destined or fixed history, what now? For Aron, this meant a call for action, a call for judgment. Since there is no fixed historical point of view, it is up to ourselves to engage ourselves in a political struggle of our own choosing. This is also what Aron appreciated in Weber:

There is no politics except in the world, and no action except in the present [...] His politics were not those of a littérateur or moralist, but those of a historian and man of action. They were not a system, or a collection of mere opinions, but judgements. To act is to make a decision, to deal with events, and to aim at an end, in a unique situation which one has not willed. Political philosophy, therefore, can be nothing but a more profound understanding of temporal action, a reflection upon the conditions within which our desires are expressed and an analysis of political choices in their relation both to reality and to our ideal. (Aron 1935, pp. 125-127) 
We have to give up any ambition for an ultimate interpretation of history. Instead, the best one could do is two things. First of all, to get informed about the specifics of the situation as best as one can. This is, for example, how Aron describes his encounters with Marxism. He started to read Marx when he was in Germany:

I wanted to find a true philosophy of history that would have the incomparable advantage of teaching us both what is and what should be. [...] But after studying Marxism for almost a whole year, I regretfully concluded that in this form it was not accurate. One could not, from the analysis of history, deduce the politics to be followed and foresee the outcome of a society from which the contradictions between humans would be eliminated. This is how I defined my ideas, to begin with, in relation to Marxism. (Aron 1971, p. 51)

Nonetheless, in his later work he would not dismiss Marx outright, still dedicating numerous courses at the Sorbonne and the Collège de France to Marx' philosophy (see Aron 2002). At the same time, he was less patient with Marxists and communists. He would famously argue that Marxism became 'an opium for the intellectuals' (Aron 1955). The problems with Marxists was not so much their specific positions, but the dogmatism by which they endorsed them. And that dogmatism was, on its turn, problematic because of its political consequences: it served as a permit for the Soviet Union to do whatever it wanted, while Western countries were scrutinized for all their mistakes. "We judge capitalism on its faults or its inadequacies, yet we ultimately judge socialism on its ultimate intention." (Aron 1961, p. 42) In reality, according to Aron, both capitalism and communism actually shared most of their values and both aimed to practically live up to them. The issue was therefore not to dogmatically focus on their values, but empirically study their implementation and effects:

The development of productive forces in order to ensure for all humans the conditions of an honorable existence, the refusal of inequalities by birth, the consecration of legal and moral equality of citizens. The ideals of economic growth and universal citizenship equally characterize the so-called popular democracy regimes and the so-called Western democratic regimes. Neither regime is entirely true to its own principles. (Aron 1961, p. 264)

Secondly, the plurality of history led to Aron's principle that one should always be open for a dialogue with others. Again, this was the lesson he drew from his encounters with fascists and communists alike. Though both often accepted the same empirical and historical facts, they organized them radically different in their ideology:

In our time [...] we have encountered the other at our side. It was not necessary to sail to a distant and unknown country to ask oneself: how can one be a Persian? It is enough to meet one's colleague, at one's side, to ask: how can he be a Hitlerian? or a Stalinist? [...] This political 
relativism, the equivalent of historical relativism, can be refuted or surmounted by the analyst by either excluding one of the schools from science or discerning partial truths in both. Personally, I draw two lessons: one must understand incompatible visions in academic disciplines and in the ideologies of political parties; and one must justify the taking of a stand by the study of the regimes our period offers. (Aron 1978, p. xxv)

Aron mainly found such openness for other perspectives in democratic regimes and institutions, which he therefore found superior to their totalitarian counterparts. Part of the justification for democratic regimes thus resides in one's view of history. Aron pleaded for what we could call a liberal historicism: the plurality of history implied a tolerance towards different points of views, at least as a starting point. In contrast, a closed view on history, which he associated with Marxism, implied a closed, dogmatic politics. If one already knows what the meaning of history is, one does not have to put up the effort to understand the other. "A true understanding of the past recalls us to the duty of tolerance; a false philosophy of history breeds only fanaticism." (Aron 1955, p. 170)

\subsection{The human as a historical being}

Aron's philosophy of history, however, has a second central starting point, that is seemingly at odds with the first principle. If there is indeed a plurality of history, how does one then take a stance? And what would be the ground of such a stance? In other words, the first principle still risks to fall back on a form of relativism or fatalism about history and politics. Aron's way out is, as we have alluded to in the previous section, an existentialist theme, stressing the role of resolute action and decision. More generally, he grounds this in a phenomenological argument: as humans in the world we always experience history as a whole, with a unified meaning.

This is because history is not purely a scientific activity, but also a human activity (an idea we already encountered in Aron's reflections on biology). This has repercussions on how to understand our relation to historiography. The origin of our interest in historical narratives, Aron argues, lies in our desire for self-understanding. His dissertation, for instance, follows this structure: it starts by raising the question of the knowledge of ourselves, then goes on to knowledge about others, about our collectives and finally comes to historical knowledge. The desire behind historical knowledges is thus first of all a desire to understand oneself:

Historical knowledge is part, it is a means, of the knowledge of self. I discover the past of my collectivity partly in myself: when I interest myself in it, [...] I am trying to find out how my collectivity became what it is, how it made me what I am. Moreover, if I am, first and foremost, what my milieu and my environment have made me, if I do not spontaneously distinguish between the ideas I have received and my ideas, I am condemned to explore the world of 
mankind in order to show what perhaps makes me unique, and what, in any case, is mine, essentially because I have sanctioned it by my choice. (Aron 1938a, p. 84)

It therefore typically starts from an imaginary narrative about the society one lives in. In response, a critical or scientific historiography arises, which problematizes these starting myths. Instead, it wants to find out how the specific history 'really' looked like. But, so Aron argues, following this second critical moment, there is "a third, that of critical reflection, which does not reject scientific effort like it rejects mythological complacency, but which determines its limits and its own value." (Aron 1961, p. 13) This reflexive moment makes us reflect on why we raise historical questions. Aron, for instance, thinks of Nietzsche's 'On the Use and Abuse of History for Life', which embodies this reflexive moment: "History is always at the service of life, whether it offers models, judges the past or situates the current moment in becoming. History expresses a dialogue of the present and the past in which the present takes and maintains the initiative." (Aron 1961, p. 14)

This practical need for history in life, however, is often not recognized in the theories of historians or sociologists, who stick to the second, critical phase. In fact, they often celebrate this moment, for instance under the label of Weber's disenchantment of the world. Aron sees similar themes at work in Jacques Monod's view on life, developed in Le hasard et nécessité (1970) and even in Gaston Bachelard's work, especially in La philosophie du non: "The world in which we think is not the world in which we live." (Bachelard 1940, p. 110; quoted in Aron 1971, p. 23) Similarly how the biologist and physicist presents us with a worldview devoid of ordinary meaning, sociology disenchants the world: "To our customs, our beliefs, even those which are sacred to us, it ruthlessly appends the adjective 'arbitrary'." (Aron 1971, p. 23) But, the paradox is that, of course, scholars live in our world as well and thus cannot simply escape this need to situate themselves historically. Aron therefore notes, how, these scholars typically do find a way to live in this universe which they believe is devoid of all meaning:

In truth, each of us strives in our own way to overcome it. Bachelard sought in poetic surreality the warmth of a refuge emerging from the frozen universe of science, but he remained a spectator of the tumult of history; he psychoanalyzed the dreams of mankind, not those of individuals. (Aron 1971, p. 24) ${ }^{4}$

It is therefore also that Aron stresses that he is talking about a philosophy of history, not a scientific historiography. Both exist next to one another, which is the central paradox for Aron: history is always

\footnotetext{
${ }^{4}$ As one of the reviewers correctly notes, it can be contested to what extent Bachelard (and Monod) practically 'remained a spectator of the tumult of history'. Bachelard served for several years in the trenches of the First World War and also engages with the resistance during the Second World War. He collaborated with several resistance newspapers and publishers and even officially requested a pardon for Cavaillès. Monod similarly engaged in history, again as part of the resistance in the Second World War, but also during the May 68 student protests.
} 
a way how human orientate themselves (we are historical beings), though this is scientifically impossible (because history is plural). More specifically, we are faced with "two fundamental antinomies [...] the first between historical relativity, which seems a fact, and universal truth required by reason, and the other between individual perspectives, partial and multiple, and the totality of historical development" (Aron 1938b, p. 294). For Aron, these paradoxes do not constitute a problem for his philosophy, but rather forms the center of his political stance, that of a engaged spectator.

\subsection{The Engaged Spectator}

History is for Aron always a means to situate oneself. Therefore to pick a certain philosophy of history is to pick a certain subjectivity. In that sense, what Aron is after is to formulate an alternative moral model of the self, which can replace that of Brunschvicg. When Aron is pleading for a specific liberal historicism, he does so to constitute a specific, liberal self: one that is tolerant towards others and is capable to live in the paradoxical stance described above. At multiple occasions he labels this stance that of an 'engaged spectator':

I had decided to be an 'engaged spectator'. Both the spectator of the story being made, of trying to be as objective as possible with regard to the story that is being made, and at the same time not to be totally detached, to be engaged. I wanted to combine the double attitude of actor or spectator. I wrote the Introduction à la philosophie de l'histoire to show the limits within which one can be both a pure spectator and an actor. It forms 'the limits of historical objectivity'. This subtitle did not mean that I despised objectivity, on the contrary, it meant that the more we want to be objective, the more it is necessary to know from what point of view, from what position we express ourselves and we look at the world. (Aron 1981, p. 307)

The engaged spectator is one who is on the one hand aware of the plurality of history, but on the other hand consciously takes a stance and engages itself with one particular historical and political narrative. This narrative itself cannot be scientifically grounded, but is nonetheless existentially necessary. This is what Aron himself practiced in his political stance, shifting his engagement around the Second World War from a revolutionary to a conservative stance:

What I'm trying to analyze, to highlight, is that to think politically in a society, you first have to make a fundamental choice. This fundamental choice is to accept the kind of society we live in, or to refuse it. Either we are revolutionary, or we are not. If we are revolutionary, if we refuse the society in which we live, we choose violence and adventure. From this fundamental choice, there are decisions, and ad hoc decisions, by which the individual defines himself. After 1945, I tried to explain why I did not want to align myself with that which represented an alternative to the existing society. (Aron 1981, p. 55) 
Aron would also link it to Weber's distinction between a an ethics of conviction and an ethics of responsibility: whereas in the first one acts out of a moral ground, the second one takes into account the specific realities and possibilities and acts pragmatically (see Breiner 2011). But again, for Aron the engaged spectator combines both these stances simultaneously: the fundamental choice implies a moral ground, but by being aware of the historical plurality one creates room to examine the existing empirical details.

Inspired by Machiavelli, Aron also compares the task of the philosopher with that of the advisor of the Prince. Whereas a closed or determinist philosophy of history starts from a political ideal of being a 'confidant of providence', liberal historicism instead leads the philosopher to the task of being the Prince's advisor. According to Aron, in the role of the prince's advisor, "the politician does not know the future, he knows the reality and he tries to navigate as well as possible, as tight as possible" and instead "the prince's advisor is the one who helps the prince to know the situation in which he lives, which can be done depending on the events, without having the pretension or the illusion of knowing the outcome of the drama or the tragedy called human history." (Aron 1981, p. 311) Already in his dissertation, Aron (1938a) would also describe this as the opposition between a 'politics of Reason', claiming to know the ultimate truth about history, and a 'politics of understanding', which endorses historical plurality. Aron clearly opted for the latter.

\section{Conclusion}

We have seen how the philosophy of history of Aron can be situated in relation to the moral project of his supervisor, Léon Brunschvicg. Moreover, such a perspective highlights how Aron's project is not so much a purely theoretical project, but first of all a political intervention: the development of a philosophy of history required for a time faced with totalitarianism. Aron's philosophy put two paradoxical principles at its center: the plurality of history and the historicity of the human, resulting in the need for a unifying historical narrative. Rather than to solve the paradox, Aron argues through the notion of the engaged spectator that the philosopher ideally combines both.

Let me end this article, by briefly exploring whether this moral model of Aron can also contribute to contemporary reflections on historical epistemology (Braunstein, Diez and Vagelli 2019) or related disciplines such as integrated history and philosophy of science (iHPS) (Herring, Jones, Kiprijanov and Sellers 2019). I believe it can. First of all, it is clear that Aron's historical relativism, stressing the plurality of history, has affinities with contemporary debates on pluralism in science (Kellert, Longino and Waters 2006). This pluralism argues that there is not one science or scientific approach which should and can dominate in the way how we understand the world and its history. Instead one should be open for a dialogue between the different approaches within science. 
Though this is therefore not a new idea, what Aron might add to this, is the other element of his engaged spectator. Also in science it seems to be the case that, although this pluralism has to be acknowledged, there is simultaneously an existential need for the individual scientists to engage themselves in a certain historical narrative about science. Even though from a historiographical point of view no narrative is to be privileged, the choice for such a narrative in the history of science seems to be existentially required: one can only do science in a meaningful way by situating oneself in a certain narrative about what science is, where it comes from, and where it is heading. These narratives, moreover, also play a crucial role in the politics of science, ranging from the struggles for funding to debates about science's ultimate epistemic goals. A purely pluralist point of view could only debunk existing candidates for such a narrative, showing that there are alternative narratives, but would never introduce a convincing alternative. A proper engaged spectator would recognize the need for this, without giving up pluralism.

In fact, within the literature in recent history and philosophy of science there are already a number of philosophical projects coming close to such a engaged spectator. Let me end by naming three of them, reinterpreting them from the perspective of Aron. First of all, there is what in recent years Thomas Pradeu has start calling philosophy in science (PinS): philosophy of science seen, not solely as a reflection on philosophical themes in science, but as an active interventions within science in order to help it improve itself (e.g. Laplane et al. 2019; Pradeu et al. 2021). They conceptualize the role of the philosopher in science exactly as a engaged spectator: one who is aware of the plurality of perspectives, but nonetheless engages oneself in the specific debates and controversies.

Such a stance is also possible within the history of science, for example in Hasok Chang's idea of complementary science, as introduced in his book Inventing Temperature:

Complementary science asks scientific questions that are excluded from current specialist science. It begins by re-examining the obvious, by asking why we accept the basic truths of science that have become educated commonsense. Because many things are protected from questioning and criticism in specialist science, its demonstrated effectiveness is also unavoidably accompanied by a degree of dogmatism and a narrowness of focus that can actually result in a loss of knowledge. History and philosophy of science in its 'complementary' mode can ameliorate this situation (Chang 2004, p. 3)

Complementary science, thus, reexamines the history of science, bringing forgotten but potentially fruitful avenues back to the surface. According to Chang, therefore, "history and philosophy of science can seek to generate scientific knowledge in places where science itself fails to do so" (Chang 2004, p. 
236). Again, it is through his or her role as a spectator, that one can engage with contemporary scientific debates in novel ways.

A final example that I wish to mention is the empirical philosophy of science of Sabina Leonelli (e.g. Leonelli 2016; Beaulieu and Leonelli 2021). Similar to Pradeu and Chang, she exemplifies how philosophy of science should not only describe its object, but also actively contribute to its development, by taking conscious stances, for instance about the politics of data and open access in contemporary science. We, thus, find here an additional element, that is still missing in Pradeu and Chang. The engaged spectator can and should not only contribute to the internal debates in science, but also to the broader debates about the institutions of science and their politics. Similar to how Aron proposed a political philosophy of history, one should engage in a political philosophy of science.

\section{Bibliography}

Aron, Raymond. 1932. «La Pensée de M. Léon Brunschvicg: à propos de son dernier ouvrage (De la Connaissance de soi). » Revue de synthèse 4: 193-207.

Aron, Raymond. 1935. La sociologie allemande contemporaine. Paris: Alcan.

Aron, Raymond. 1938a. Introduction à la philosophie de l'histoire: Essai sur les limites de l'objectivité historique. Paris: Gallimard.

Aron, Raymond. 1938b. Essai sur la théorie de l'histoire dans l'Allemagne contemporaine. La philosophie critique de l'histoire. Paris: Vrin.

Aron, Raymond. 1945. "La philosophie de Léon Brunschvicg. " Revue de métaphysique et de morale 50(1/2): 127-140.

Aron, Raymond. 1946. "États démocratiques et États totalitaires (Juin 1939). » Bulletin de la Société française de philosophie 40(2): 41-55.

Aron, Raymond. 1955. L'opium des intellectuels. Paris: Calmann-Lévy.

Aron, Raymond. 1961. Dimensions de la conscience historique. Paris: Plon.

Aron, Raymond. 1962. « Préface. » Pp. 11-16 in Philosophie mathématique. By Jean Cavaillès. Paris: Hermann.

Aron, Raymond. 1971. « De la condition historique du sociologue. » Social Science Information 10(1): 7-29.

Aron, Raymond. 1975. History and the dialectic of violence: An analysis of Sartre's Critique de la raison dialectique. Oxford: Blackwell. 
Aron, Raymond. 1978. Politics and history : Selected essays. New York (N.Y.): Free Press.

Aron, Raymond. 1981. Le spectateur engagé. Paris: Julliard.

Aron, Raymond. 1983. Mémoires. Paris: Julliard.

Aron, Raymond. 2002. Le marxisme de Marx. Paris: Ed. de Fallois.

Cavaillès, Jean and Raymond Aron. 1939. "Introduction. " Pp. iii in Nouvelles recherches sur la structure dialectique des mathématiques. By Albert Lautman. Paris: Hermann.

Bachelard, Gaston. 1938. La formation de l'esprit scientifique: Contribution à une psychanalyse de la connaissance objective. Paris: Vrin.

Bachelard, Gaston. 1940. La philosophie du non: Essai d'une philosophie du nouvel esprit scientifique. Paris: PUF.

Barilier, Etienne. 1987. Les petits camarades: Essai sur Jean-Paul Sartre et Raymond Aron. Paris: Julliard.

Beaulieu, Anne and Sabina Leonelli. 2021. Data and Society: A Critical Introduction. London: Sage.

Braunstein, Jean-François, Ivan Moya Diez, and Matteo Vagelli. (eds.) 2019. L'épistémologie historique : Histoire et méthodes. Paris : Éditions de la Sorbonne.

Breiner, Peter. 2011. "Raymond Aron's engagement with Weber: Recovery or retreat?" Journal of Classical Sociology 11(2): 99-121.

Brunschvicg, Léon. 1923. « La relation entre le mathématique et le physique. » Revue de métaphysique et de morale 30(3): 353-363.

Brunschvicg, Léon. 1927. Le progrès de la conscience dans la philosophie occidentale. Paris: Alcan.

Brunschvicg, Léon. 1931. De la connaissance de soi. Paris: Alcan.

Castelli Gattinara, Enrico. 1998. Les inquiétudes de la raison. Paris: Vrin.

Chang, Hasok. 2004. Inventing temperature: Measurement and scientific progress. New York (N.Y.): Oxford University Press.

Chimisso, Cristina. 2001. Gaston Bachelard: critic of science and the imagination. London: Routledge. Chimisso, Cristina. 2008. Writing the history of the mind: Philosophy and science in France, 1900 to 1960s. Aldershot: Ashgate.

Colquhoun, Robert. 1986. Raymond Aron. 1: The philosopher in history 1905 - 1955. Beverly Hills: Sage. Davenson, Henri 1939. «Tristesse de l'historien ». Esprit 79: 11-47. 
Fessard, Gaston. 1980. La philosophie historique de Raymond Aron. Paris: Julliard.

Gabel, Isabel. 2018. "From evolutionary theory to philosophy of history: Raymond Aron and the crisis of French neo-transforimism." History of the Human Sciences 31(1): 3-18.

Groethuysen, Bernard. 1939. "Une Philosophie critique de I'histoire. " Nouvelle revue française 53: 623-629.

Herring, Emily, Kevin Jones, Konstantin Kiprijanov, and Laura Sellers (eds.). 2019. The Past, Present, And Future of Integrated History and Philosophy Of Science. London: Routledge.

Kellert, Stephen, Helen Longino, and C. Kenneth Waters. 2006. Scientific Pluralism. Minneapolis: University of Minnesota Press.

Laplane, Lucie, Mantovani, Paolo, Adolphs, Ralph, Chang, Hasok, Mantovani, Alberto, McFall-Ngai, Margaret, Rovelli, Carlo, Sober, Elliot, Pradeu, Thomas. 2019. “Opinion: Why science needs philosophy." Proceedings of the National Academy of Sciences - PNAS 116(10): 3948-3952.

Leonelli, Sabina. 2016. Data-centric biology: A philosophical study. Chicago: University of Chicago Press.

Monod, Jacques. 1970. Le hasard et la nécessité: Essai sur la philosophie naturelle de la biologie moderne. Paris: Seuil.

Nizan, Paul. (1932) 1971. The Watchdogs: Philosophers and the Established Order. trans. Paul Fittingoff. New York: Monthly Review Press.

Piaget, Jean. 1926. La représentation du monde chez l'enfant. Paris: Alcan.

Pradeu, Thomas., Lemoine, M., Khelfaoui, M., and Gingras, Y. 2021 - epub ahead of print. "Philosophy in Science: Can philosophers of science permeate through science and produce scientific knowledge?" The British Journal for the Philosophy of Science.

Sartre, Jean. 1960. Critique de la raison dialectique précédé de Questions de méthode. 1: Théorie des ensembles pratiques. Paris: Gallimard.

Schrift, Alan. 2006. Twentieth-Century French Philosophy: Key Themes and Thinkers. Oxford: Blackwell. Serres, Michel. (1970) 2019. "Reformation and the Seven Sins." Parrhesia: a journal of critical philosophy 31: 33-47.

Simons, Massimiliano. 2022. Michel Serres and French Philosophy of Science: Materiality, Ecology and Quasi-Objects. London: Bloomsbury.

Sirinelli, Jean-François. 1995. Deux intellectuels dans le siècle, Sartre et Aron. Paris: Fayard. 
Stewart, lain. 2009. "Existentialist manifesto or conservative political science? Problems in interpreting Raymond Aron's Introduction à la philosophie de I'histoire." European Review of History = Revue Européene D'histoire 16(2): 217-233.

Stewart, lain. 2011. "Sartre, Aron and the Contested Legacy of the Anti-Positivist Turn in French Thought, 1938-1960." Sartre Studies International 17(1): 41-60.

Terzi, Pietro. 2022. Rediscovering Léon Brunschvicg's Critical Idealism. Philosophy, History and Science in the Third Republic. London: Bloomsbury.

Verstraeten, Pierre. 2008. L'Anti-Aron. Paris: Editions de la différence. 